\title{
The Copernican Achievement
}

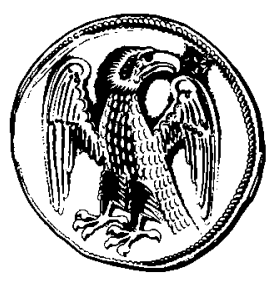

Published under the auspices of the CENTER FOR MEDIEVAL AND RENAISSANCE STUDIES

University of California, Los Angeles 
Contributions of the

UCLA CENTER FOR MEDIEVAL AND RENAISSANCE STUDIES

1: Medieval Secular Literature: Four Essays. Ed. William Matthews

2: Galileo Reappraised. Ed. Carlo L. Golino

3: The Transformation of the Roman World. Ed. Lynn White, jr.

4: Scientific Methods in Medieval Archaeology. Ed. Rainer Berger

5: Violence and Civil Disorder in Italian Cities, $1200-1500$. Ed. Lauro Martines

6: The Darker Vision of the Renaissance: Beyond the Fields of Reason. Ed. Robert S. Kinsman

7: The Copernican Achievement. Ed. Robert S. Westman 
UCLA CENTER FOR

MEDIEVAL AND RENAISSANCE STUDIES

CONTRIBUTIONS: VII

\title{
The Copernican Achievement
}

Edited by

\author{
ROBERT S. WESTMAN
}

UNIVERSITY OF CALIFORNIA PRESS

BERKELEY • LOS ANGELES • LONDON 1975 
University of California Press

Berkeley and Los Angeles, California

University of California Press, Ltd.

London, England

Copyright (C) 1975 by The Regents of the University of California ISBN: 0-520-02877-5

Library of Congress Catalog Card Number: 74-22974

Printed in the United States of America 
For Joseph, Claire, Walter,

and Robin 
